Aos poucos os países da América Latina constroem um relacionamento mais maduro

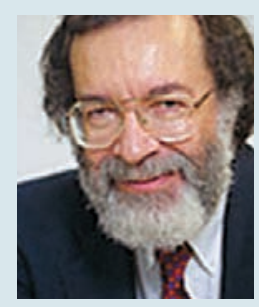

ENRIQUE SARAVIA FGV Projetos enrique.saravia@fgv.br

\title{
"TODO NOS UNE, NADA NOS SEPARA"
}

Durante séculos, os países sul-americanos se ignoraram mutuamente. A atenção dirigia-se às metrópoles políticas e econômicas e os vizinhos não interessavam. Depois que proclamaram sua independência, nas primeiras décadas do século XIX, as nações só se encontravam em esporádicas e cruentas guerras. A desconfiança e o desconhecimento corroíam o relacionamento.

No final dos anos 1970, dois acordos diplomáticos deram início a um relacionamento mais maduro entre os países. O Acordo Tripartite para o Aproveitamento Hidrelétrico da Bacia do Prata, firmado entre Argentina, Brasil e Paraguai, em 1979, e o Acordo de Desenvolvimento e Aplicação Pacífica da Energia Nuclear, celebrado por Brasil e Argentina em 1980, acabaram com rivalidades tradicionais, artificialmente alimentadas, que separavam os países e ameaçavam a estabilidade na região.

Outro avanço significativo foi a criação do Mercosul, em 1991. Dois anos depois, quando as esperanças de integração estavam quase intactas, a agência Ogilvy \& Mather fez uma pesquisa de opinião, consultando 530 empresários dos quatro países sócios (Argentina, Brasil, Paraguai e Uruguai) acerca das expectativas e iniciativas a respeito do novo mercado e da imagem mútua dos empresários de cada um dos países. A imagem das empresas brasileiras era altamente favorável (80\%). Perguntados sobre os aspectos positivos do Brasil, os empresários dos países vizinhos destacavam o fato de ser um país imenso, desenvolvido tecnologicamente e com elevada capacidade produtiva, ainda que mal aproveitada, e com um enorme mercado de consumo. Como aspectos negativos, mencionavam corrupção e desigualdades sociais. Mas, em suma, consideravam o Brasil um parceiro confiável.

Desde então, a situação econômica dos países do Mercosul melhorou, particularmente no
Brasil. A Argentina, apesar de suas crises profundas e frequentes, continua crescendo, o Paraguai e o Uruguai se aperfeiçoaram politicamente e a Venezuela também se incorporou ao grupo.

O ingresso deste último país, ainda dependente de aprovação pelo congresso paraguaio, vinha sendo negociado há vários anos com amplo respaldo dos governos e da opinião pública. Com a Venezuela, o Mercosul deixaria de ser um evento distante para a região norte do Brasil, e o país passaria a ser central dentro do sistema. A Venezuela contribuiria com seus enormes recursos naturais e abriria seu mercado para os produtos e serviços brasileiros. Essa aproximação levou a concretizações importantes, como a construção da autoestrada Manaus-Caracas e a conexão entre a hidrelétrica venezuelana do Guri e o Estado de Roraima. Embora o comportamento extravagante do presidente Hugo Chávez tenha complicado o quadro, acabou prevalecendo a sabedoria política: "Os governos passam, mas os países ficam."

Esses eventos foram criando aquilo que os juristas romanos denominavam de affectio societatis: a vontade das partes de dedicar esforços a fim de atingir um fim desejado por todos, vontade que os romanos elevaram a requisito indispensável dos contratos. Tudo indica que a affectio entre o Brasil e seus vizinhos cresce e que o desejo de consolidar e expandir a comunidade permanece.

Dir-se-á que a vocação internacional do Brasil de hoje é bem mais ambiciosa que uma união com seus vizinhos, o que é verdade. Mas nada impede um avanço coletivo em direção a metas que favoreçam o conjunto.

A geografia mantém-nos indissoluvelmente unidos. O tempo vem confirmando a frase que o presidente argentino Roque Sáenz Peña escreveu para o Barão do Rio Branco em 1912: "Todo nos une, nada nos separa." Com exceção do futebol, claro. 